\title{
Could earnings momentum crash?
}

\author{
Min Zhang ${ }^{*}$, Wenbin Bao \\ School of Economics and Management, Nanjing University of Science and \\ Technology, China \\ *Corresponding author: Wenbin Bao, Associate Professor, baowenbin@sohu.com
}

\begin{abstract}
It is already accepted by researchers that price momentum has crashed. How about earnings momentum? Does it also have crashed? In this paper we used two methods--- standardized unexpected earnings and the cumulative abnormal stock return to measure earnings momentum which are supposed to put into ten portfolios to calculate the extreme momentum returns. We found that the standardized unexpected earnings (SUE) had perfect performance after the year of 2000 which was the momentum crash period. On the contrary, the cumulative abnormal stock return (ABR) had crashed strongly after 2000.So we can easily to conclude earnings momentum had crashed when we measured it through SUE, but it had crashed when we measured it through ABR.
\end{abstract}

Key words: momentum crashes; earnings momentum; portfolio; return

\section{Introduction}

A momentum strategy is a bet on past returns predicting the cross-section of future returns, which is typically implemented by buying past winners and selling past losers ${ }^{1}$. Momentum is pervasive and the academic documents has kept track of the economy of momentum strategies across multiple periods, many markets, and in numerous asset classes. ${ }^{2}$

Specially, the phenomenon of earnings momentum in the stock market is a kind of vision caused by investors' irrational reaction to the market. And for a period in the future, the former rate of return is still higher than the latter one. Latane and Jone, Bernard, and Thomas have confirmed that there are surplus momentum effects in the market within half a year after the earnings announcement. ${ }^{3}$ In our country, Wu Shinong and $\mathrm{Wu}$ Chaopeng have been doing empirical research on the momentum strategy in Shanghai stock market from 1997 to 2002. It is found that the sample stock has obtained the excess return of up to $4.11 \%$ in the half year after the combination, which achieves $1 \%$ Level. ${ }^{4}$ This result has verified the "under reaction" mode.

However, the strong positive average returns and Sharpe ratios of momentum strategies are punctuated with occasional crashes. Like the returns to the carry trade in currencies, momentum returns are negatively skewed, and the negative returns can be 
pronounced and persistent. In 1927 to 2013 U.S. equity sample, the two worst months for a momentum strategy that buys the top decile of past 12-month winners and shorts the bottom decile of losers are consecutive: July and August of 1932. Over this short period, the past-loser decile portfolio returned 232\%, while the past-winner decile portfolio had a gain of only 32\%. In a more recent crash, over the three-month period from March to May of 2009, the past-loser decile rose by $163 \%$, while the decile portfolio of past winners gained only $8 \%{ }^{5}$

\section{Sample and methodology}

We consider all domestic, primary stocks listed on the New York (NYSE), American (AMEX), and NASDAQ stock markets. Closed-end funds, Real Estate Investment Trusts (REITs), trusts, American Depository Receipts (ADRs), and foreign stocks are excluded from the analysis. Since we require information on earnings, the sample comprises all companies with coverage on both the Center for Research in Security Prices (CRSP) and COMPUSTAT (Active and Research) files. ${ }^{6}$ The data for firms in this sample are supplemented, wherever available, with data on analysts' forecasts of earnings from the Lynch, Jones, and Ryan Institutional Brokers Estimate System (I/B/E/S) database. At the beginning of every month from 1976 to 2016, we rank stocks on the basis of either past returns or a measure of earnings news. To be eligible, a stock need only have data available on the variable(s) used for ranking, even though we provide information on other stock attributes. The ranked stocks are then assigned to one of ten decile portfolios, where the breakpoints are based only on NYSE stocks. In my earnings momentum strategies, the breakpoints in any given month are based on all NYSE firms that have reported earnings within the prior three months. This takes into account a complete cycle of earnings announcements. All stocks are equally weighted within a given portfolio.

The ranking variable used in our price momentum strategy is a stock's past compound return, extending back six months prior to portfolio formation. In my earnings momentum strategies, we use three different measures of earnings news. Our first is the commonly used standardized unexpected earnings (SUE) variable. Foster, Olsen, and Shevlin (1984) examine different time series models for expected earnings and how the resulting measures of unanticipated earnings are associated with future returns. They find that a seasonal random walk model performs as well as more complex models, so I use it as our model of expected earnings. ${ }^{7}$ The SUE for stock i in month $t$ is thus defined as

$$
\mathrm{SUE}_{\mathrm{it}}=\frac{\mathrm{e}_{\mathrm{iq}}-\mathrm{e}_{\mathrm{iq}-4}}{\sigma_{\mathrm{it}}}
$$

Where $e_{i q}$ is quarterly earnings per share most recently announced as of month $t$ for stock $\mathrm{i}, \mathrm{e}_{\mathrm{iq}-4}$ is earnings per share four quarters ago, and $\sigma_{\mathrm{it}} \mathrm{is}$ the standard deviation 
of unexpected earnings, $\mathrm{e}_{\mathrm{iq}}-\mathrm{e}_{\mathrm{iq}-4}$ over the preceding eight quarters. ${ }^{8}$

Another measure of earnings surprise is the cumulative abnormal stock return around the most recent announcement date of earnings up to month $t$, ABR, defined as

$$
\mathrm{ABR}_{\mathrm{it}}=\sum_{\mathrm{j}=-2}^{+1}\left(\mathrm{r}_{\mathrm{ij}}-\mathrm{r}_{\mathrm{mj}}\right)
$$

Where $r_{i j}$ is stock i's return on day $j$ (with the earnings being announced on day 0 ) and $r_{m j}$ is the return on the equally-weighted market index. We cumulate returns until one day after the announcement date to account for the possibility of delayed stock price reaction to earnings news, particularly since our sample includes NASDAQ issues that may be less frequently traded. ${ }^{9}$ This return-based measure is a fairly clean measure of earnings surprise, since it does not require an explicit model for earnings expectations. However, the abnormal return around the announcement captures the change over a window of only a few days in the market's views about earnings. The SUE measure incorporates the information up to the last quarter's earnings and hence in principle measures earnings surprise over a longer period.

\section{Earnings momentum}

Investment rules based on standardized unexpected earnings (SUE) have a long history dating back at least to Jones and Litzenberger (1970). Accordingly, Table 1 starts off our evaluation of earnings momentum by applying a strategy based on SUE as a measure of the news in earnings. At the beginning of every month from January 1976 to December 2016 all stocks are ranked by their most recent past standardized unexpected earnings and assigned to one of ten portfolios. The first column reports the year from 1976 to 2000's mean return for each portfolio which used the way of Jegadeesh and Titman (1993) to form the portfolio. The second column reports the the year from 2000 to 2016's mean return for each portfolio which the period has momentum crash and the third column reports all the sample period the performance about earnings momentum in SUE.

In the first column is the year from 1976 to 2000 which had no crash between these years, we can find the arbitrage portfolio(portfolio 10 minus portfolio 1)earns a return of 0.505 percent each month in equally-weighted and 0.504 percent in value-weighted. At the second column is the year from 2000 to 2016 which have momentum crash, the extreme returns in equally-weighted is 0.801 percent each month and 0.796 percent in value-weighted much better than the period which have no momentum crash. Obviously, the earnings momentum measured use SUE was no momentum crash while have very excellent performance in crash period. The third column is all of sample from 1976 to 2016, whether equally-weighted or value-weighted both are perfect performance. In the period following portfolio formation, the behavior of 
subsequent standardized unexpected earnings and consensus estimates also shows delays in the adjustment of forecasts. The sustained nature of the adjustment in analyst forecasts is particularly notable in the case of firms in portfolio 1with large unexpected declines in earnings.

Table 1-Mean Returns for Portfolios Classified by Standardized Unexpected Earnings

\begin{tabular}{|c|c|c|c|c|c|c|}
\hline & \multicolumn{2}{|c|}{$1976-2000$} & \multicolumn{2}{|c|}{$2000-2016$} & \multicolumn{2}{|c|}{ 1976-2016 } \\
\hline & $\begin{array}{l}\text { equally-weigh } \\
\text { ted }\end{array}$ & $\begin{array}{l}\text { value-weigh } \\
\text { ted }\end{array}$ & $\begin{array}{l}\text { equally-weigh } \\
\text { ted }\end{array}$ & $\begin{array}{l}\text { value-weigh } \\
\text { ted }\end{array}$ & $\begin{array}{l}\text { equally-weigh } \\
\text { ted }\end{array}$ & $\begin{array}{l}\text { value-weigh } \\
\text { ted }\end{array}$ \\
\hline P1 & $\begin{array}{r}1.982 * * * \\
(3.72)\end{array}$ & $\begin{array}{r}1.894 * * * \\
(3.61)\end{array}$ & $\begin{array}{c}0.66 \\
(1.09)\end{array}$ & $\begin{array}{c}0.58 \\
(0.96)\end{array}$ & $\begin{array}{r}1.299 * * * \\
(3.14)\end{array}$ & $\begin{array}{r}1.206^{* * *} \\
(2.95)\end{array}$ \\
\hline P2 & $\begin{array}{r}1.826 * * * \\
(4.26)\end{array}$ & $\begin{array}{r}1.76^{* * *} \\
(4.17)\end{array}$ & $\begin{array}{l}0.992 * \\
\text { (1.93) }\end{array}$ & $\begin{array}{l}0.938 * \\
(1.83)\end{array}$ & $\begin{array}{r}1.386 * * * \\
(4.03)\end{array}$ & $\begin{array}{r}1.327 * * * \\
(3.90)\end{array}$ \\
\hline P3 & $\begin{array}{r}1.566 * * * \\
(4.31)\end{array}$ & $\begin{array}{r}1.515 * * * \\
(4.23)\end{array}$ & $\begin{array}{l}0.979 * * \\
(2.10)\end{array}$ & $\begin{array}{r}0.946 * * \\
(2.04)\end{array}$ & $\begin{array}{r}1.264 * * * \\
(4.21)\end{array}$ & $\begin{array}{r}1.222 * * * \\
(4.10)\end{array}$ \\
\hline $\mathrm{P} 4$ & $\begin{array}{r}1.543 * * * \\
(4.64)\end{array}$ & $\begin{array}{r}1.495 * * * \\
(4.57)\end{array}$ & $\begin{array}{l}0.985^{* *} \\
(2.48)\end{array}$ & $\begin{array}{r}0.957 * * \\
(2.42)\end{array}$ & $\begin{array}{r}1.233^{* * * *} \\
(4.76)\end{array}$ & $\begin{array}{r}1.194 * * * \\
(4.65)\end{array}$ \\
\hline P5 & $\begin{array}{r}1.71^{* * * *} \\
(4.90)\end{array}$ & $\begin{array}{r}1.687 * * * \\
(4.90)\end{array}$ & $\begin{array}{r}1.08 * * * \\
(2.91)\end{array}$ & $\begin{array}{r}1.045^{* * *} \\
(2.84)\end{array}$ & $\begin{array}{r}1.37 * * * \\
(5.39)\end{array}$ & $\begin{array}{r}1.34 * * * \\
(5.33)\end{array}$ \\
\hline P6 & $\begin{array}{r}1.834 * * * \\
(5.00)\end{array}$ & $\begin{array}{r}1.803^{* * *} \\
(4.97)\end{array}$ & $\begin{array}{r}1.039 * * * \\
(2.72)\end{array}$ & $\begin{array}{r}1.011^{* * *} \\
(2.67)\end{array}$ & $\begin{array}{r}1.388^{* * * *} \\
(5.26)\end{array}$ & $\begin{array}{r}1.359 * * * \\
(5.20)\end{array}$ \\
\hline P7 & $\begin{array}{r}1.711^{* * *} \\
(4.62)\end{array}$ & $\begin{array}{r}1.67 * * * \\
(4.56)\end{array}$ & $\begin{array}{r}1.108^{* * * *} \\
(2.80)\end{array}$ & $\begin{array}{r}1.075^{* * *} \\
(2.73)\end{array}$ & $\begin{array}{r}1.393^{* * * *} \\
(5.19)\end{array}$ & $\begin{array}{r}1.357^{* * * *} \\
(5.08)\end{array}$ \\
\hline P8 & $\begin{array}{r}1.854 * * * \\
(4.89)\end{array}$ & $\begin{array}{r}1.817 * * * \\
(4.83)\end{array}$ & $\begin{array}{r}1.218^{* * *} \\
(2.95)\end{array}$ & $\begin{array}{r}1.191 * * * \\
(2.89)\end{array}$ & $\begin{array}{r}1.485^{* * * *} \\
(5.34)\end{array}$ & $\begin{array}{r}1.453 * * * \\
(5.24)\end{array}$ \\
\hline P9 & $\begin{array}{l}2.11^{* * * *} \\
(5.04)\end{array}$ & $\begin{array}{r}2.071^{* * *} \\
(5.00)\end{array}$ & $\begin{array}{r}1.244 * * * \\
(2.78)\end{array}$ & $\begin{array}{r}1.206 * * * \\
(2.70)\end{array}$ & $\begin{array}{r}1.646^{* * * *} \\
(5.37)\end{array}$ & $\begin{array}{r}1.607^{* * * *} \\
(5.28)\end{array}$ \\
\hline P10 & $\begin{array}{r}2.459 * * * \\
(4.82)\end{array}$ & $\begin{array}{r}2.372 * * * \\
(4.73)\end{array}$ & $\begin{array}{r}1.464 * * * \\
(2.65)\end{array}$ & $\begin{array}{r}1.374^{* *} \\
(2.52)\end{array}$ & $\begin{array}{r}1.947 * * * \\
(5.08)\end{array}$ & $\begin{array}{r}1.853 * * * \\
(4.90)\end{array}$ \\
\hline MOM & $\begin{array}{r}0.505^{* * *} \\
(2.90)\end{array}$ & $\begin{array}{r}0.504 * * * \\
(2.98)\end{array}$ & $\begin{array}{r}0.801 * * * \\
(4.81)\end{array}$ & $\begin{array}{r}0.796 * * * \\
(4.79)\end{array}$ & $\begin{array}{r}0.648 * * * \\
(5.44)\end{array}$ & $\begin{array}{r}0.647 * * * \\
(5.51)\end{array}$ \\
\hline
\end{tabular}

The evidence in the Table 1 is consistent with the idea that the superior stock price performance reflects the market's gradual adjustment to earnings surprises. In particular, the past SUE contains information that is not incorporated into the stock price.

Our results in Table 2 actually indicate that the performance of Abnormal Return Around Earnings Announcement was less than satisfactory in different period. At the beginning of every month from January 1976 to December2016 all stocks are ranked 
by their most recent cumulative abnormal stock return and assigned to one of ten portfolios. All stocks are equally-weighted in a portfolio. The first column reports the year from 1976 to 2000's mean return for each portfolio which used the way of Jegadeesh and Titment (2001) to form the portfolio. The second column reports the year from 2000 to 2016's mean return for each portfolio which the period has momentum crash and the third column reports all the sample period the performance about earnings momentum in ABR.

In the first column is the year from 1976 to 2000 which had no crash between these years, we can find the arbitrage portfolio(portfolio 10 minus portfolio 1)earns a return of 0.579 percent each month in equally-weighted and 0.607 percent in value-weighted. At the second column is the year from 2000 to 2016 which have momentum crash, the extreme returns in equally-weighted is 0.13 percent each month and 0.09 percent in value-weighted and not significantly. Obviously, the earnings momentum measured use ABR has very serious momentum crash. The third column is all of sample from 1976 to 2016, whether equally-weighted or value-weighted both are significance extreme portfolio returns. Tables 1 and 2 suggest the different performance about earnings momentum that help us to know the truth who make the earnings momentum crash.

\section{Conclusions}

We are familiar with earnings momentum and momentum crash, but just there is little research on the relation between them. This paper gives us an idea that the true factor leads the earnings momentum crash. The standardized unexpected earnings (SUE) have very perfect returns in the crash period, because this strategy is more rational than the cumulative abnormal stock return (ABR). It is a clear variable that just indicates the financial situation of companies. However, the cumulative abnormal stock return (ABR) contains more irrational factors. It reflects that when confronted with earning surprise and the crash of the market information, the investor's behavior will easily crash. So momentum also has caused crash in investor heart, but it never crashes in companies' view. 
Table 2-Mean Returns and Characteristics for Portfolios Classified by Abnormal Return Around Earnings Announcement

\begin{tabular}{|c|c|c|c|c|c|c|}
\hline & \multicolumn{2}{|c|}{$1976-2000$} & \multicolumn{2}{|c|}{$2000-2016$} & \multicolumn{2}{|c|}{ 1976-2016 } \\
\hline & $\begin{array}{l}\text { equally-weigh } \\
\text { ted }\end{array}$ & $\begin{array}{l}\text { value-weigh } \\
\text { ted }\end{array}$ & $\begin{array}{l}\text { equally-weigh } \\
\text { ted }\end{array}$ & $\begin{array}{l}\text { value-weigh } \\
\text { ted }\end{array}$ & $\begin{array}{l}\text { equally-weigh } \\
\text { ted }\end{array}$ & $\begin{array}{l}\text { value-weigh } \\
\text { ted }\end{array}$ \\
\hline $\mathrm{P} 1$ & $\begin{array}{r}1.899 * * * \\
(5.40)\end{array}$ & $\begin{array}{r}1.815^{* * * *} \\
(5.30)\end{array}$ & $\begin{array}{r}1.147 * * * \\
(3.48)\end{array}$ & $\begin{array}{r}1.106^{* * * *} \\
(3.39)\end{array}$ & $\begin{array}{r}1.485^{* * *} \\
(6.21)\end{array}$ & $\begin{array}{r}1.419 * * * \\
(6.05)\end{array}$ \\
\hline $\mathrm{P} 2$ & $\begin{array}{r}1.619 * * * \\
(4.82)\end{array}$ & $\begin{array}{r}1.598 * * * \\
(4.82)\end{array}$ & $\begin{array}{r}1.123^{* * *} \\
(3.32)\end{array}$ & $\begin{array}{r}1.08 * * * \\
(3.22)\end{array}$ & $\begin{array}{r}1.336^{* * *} \\
(5.62)\end{array}$ & $\begin{array}{r}1.299 * * * \\
(5.53)\end{array}$ \\
\hline P3 & $\begin{array}{r}1.782^{* * *} \\
(4.97)\end{array}$ & $\begin{array}{r}1.705^{* * *} \\
(4.91)\end{array}$ & $\begin{array}{r}1.182^{* * *} \\
(3.26)\end{array}$ & $\begin{array}{r}1.146^{* * * *} \\
(3.19)\end{array}$ & $\begin{array}{r}1.437 * * * \\
(5.69)\end{array}$ & $\begin{array}{r}1.383^{* * * *} \\
(5.58)\end{array}$ \\
\hline $\mathrm{P} 4$ & $\begin{array}{r}1.73^{* * *} \\
(5.19)\end{array}$ & $\begin{array}{r}1.669 * * * \\
(5.08)\end{array}$ & $\begin{array}{r}1.203^{* * *} \\
(3.35)\end{array}$ & $\begin{array}{r}1.159 * * * \\
(3.27)\end{array}$ & $\begin{array}{r}1.401^{* * *} \\
(5.72)\end{array}$ & $\begin{array}{r}1.348 * * * \\
(5.58)\end{array}$ \\
\hline P5 & $\begin{array}{r}1.779 * * * \\
(5.11)\end{array}$ & $\begin{array}{r}1.733^{* * * *} \\
(5.06)\end{array}$ & $\begin{array}{r}1.287 * * * \\
(3.28)\end{array}$ & $\begin{array}{r}1.241^{* * * *} \\
(3.22)\end{array}$ & $\begin{array}{r}1.484^{* * *} \\
(5.63)\end{array}$ & $\begin{array}{r}1.433^{* * * *} \\
(5.53)\end{array}$ \\
\hline P6 & $\begin{array}{r}1.932 * * * \\
(5.15)\end{array}$ & $\begin{array}{r}1.879 * * * \\
(5.08)\end{array}$ & $\begin{array}{r}1.251^{* * *} \\
(3.07)\end{array}$ & $\begin{array}{r}1.193^{* * *} \\
(2.98)\end{array}$ & $\begin{array}{r}1.549 * * * \\
(5.58)\end{array}$ & $\begin{array}{r}1.489 * * * \\
(5.46)\end{array}$ \\
\hline P7 & $\begin{array}{r}1.92^{* * *} \\
(4.87)\end{array}$ & $\begin{array}{r}1.873^{* * * *} \\
(4.84)\end{array}$ & $\begin{array}{r}1.225^{* * *} \\
(2.89)\end{array}$ & $\begin{array}{r}1.169 * * * \\
(2.78)\end{array}$ & $\begin{array}{r}1.582^{* * *} \\
(5.47)\end{array}$ & $\begin{array}{r}1.53 * * * \\
(5.37)\end{array}$ \\
\hline P8 & $\begin{array}{l}2.1^{* * *} \\
(4.90)\end{array}$ & $\begin{array}{r}2.052^{* * * *} \\
(4.86)\end{array}$ & $\begin{array}{r}1.288^{* * *} \\
(2.78)\end{array}$ & $\begin{array}{r}1.235^{* * * *} \\
(2.71)\end{array}$ & $\begin{array}{r}1.63^{* * *} \\
(5.16)\end{array}$ & $\begin{array}{r}1.572 * * * \\
(5.07)\end{array}$ \\
\hline P9 & $\begin{array}{r}2.337 * * * \\
(5.06)\end{array}$ & $\begin{array}{r}2.278^{* * * *} \\
(4.99)\end{array}$ & $\begin{array}{r}1.181^{* *} \\
(2.39)\end{array}$ & $\begin{array}{r}1.095^{* *} \\
(2.24)\end{array}$ & $\begin{array}{r}1.696^{* * *} \\
(4.97)\end{array}$ & $\begin{array}{r}1.622^{* * * *} \\
(4.80)\end{array}$ \\
\hline P10 & $\begin{array}{r}2.479 * * * \\
(4.76)\end{array}$ & $\begin{array}{r}2.421^{* * *} \\
(4.67)\end{array}$ & $\begin{array}{r}1.273^{* *} \\
(2.23)\end{array}$ & $\begin{array}{r}1.191^{* * *} \\
(2.09)\end{array}$ & $\begin{array}{r}1.925^{* * *} \\
(4.86)\end{array}$ & $\begin{array}{r}1.849 * * * \\
(4.69)\end{array}$ \\
\hline MOM & $\begin{array}{r}0.579 * * \\
(2.18)\end{array}$ & $\begin{array}{r}0.607 * * \\
(2.24)\end{array}$ & $\begin{array}{l}0.13 \\
\qquad(0.41)\end{array}$ & $\begin{array}{l}0.09 \\
\quad(0.28)\end{array}$ & $\begin{array}{l}0.377^{*} \\
(1.81)\end{array}$ & $\begin{array}{l}0.369 * \\
(1.75)\end{array}$ \\
\hline
\end{tabular}




\section{References}

1. Louis K. C. Chan, Narasimhan Jegadeesh, Josef Lakonishok. Momentum Strategies, J. The Journal of Finance, 12(1996):1681-1713.

2. Tarun Chordia, Lakshmanan Shivakumar. Earnings and price momentum, J. The Journal of Finance Economics.80 (2006):627-656.

3. DongHong,Charles Lee, Bhaskaran Swaminathan. Earning Momentum in International Markets, J. The Journal of Finance.58 (2003):1-27.

4. Titman Jegadeesh, Returns to Buying Winners and Selling Losers: Implications for Stock Market Efficiency, J. The Journal Of Finance.1 (1993):65-91.

5. N.Jegadeesh, and S. Titman. Profitability of Momentum Strategies: An Evaluation of Alternative Explanations, J. The Journal of Finance.56 (2001):699-720.

6. E. Fama, K. French. The Cross-Section of Expected Stock Returns, J. The Journal of Finance.47 (1992):427-465.

7. E. Fama, K. French. Common risk factors in the returns on stocks and bonds, J. The Journal of Finance.33 (1993):3-56.

8. G.Foster, C.Olsen, T.Shevlin, Earnings Releases Anomalies and Predictive-ability Results, J. Accounting Reviews.59 (1984):574-603.

9. A.Frazzini, The Disposition Effect and Under reaction to News. J. The Journal of Finance.4 (2006):2017-2046.

10. M.Grinblatt, B. Han. Prospect theory, mental accounting and momentum, J. Journal of Financial Economics.78 (2005):311-339.

11. H. Chen, S. Chen, C. Hsin C. ,Lee. Does Revenue Momentum Drive or Ride Earnings or Price Momentum?, J. The Journal of Banking and Finance.38 (2013):166-185.

12. N. Jegadeesh, J.Livnat ,Revenue Surprises and Stock Returns, J. Journal of Accounting and Economics.41 (2006):147-171.

13. K. Daniel, T. j., Markowitz. Momentum Crashes, J. Financial Analysts Journal. 9(2013):821-843.

15. D. Lesmond, M.Schill, C.Zhou, The illusory nature of momentum profits, J. Journal of Financial Economics. 71(2004):349-380.

16. V.L. Bemard, J. K.Thomas, Evidence That Stock Price Do Not Reflect the Implications of Current Earnings for Future Earnings, J. Journal of Accounting and Ecomomics. 13(1989):305-340.

17. G.H.Jiang, C. Lee, Y. Zhang, Information Uncertainly and Stock Returns, J. Review of Accounting Studies.10(2005):185-221.

18. Kothari S. P. Capital Markets Research in Accounting, J. Journal of Accounting and Economics, 3(2001):105-231. 